\title{
A review of tobacco abuse and its epidemiological consequences
}

\author{
Micah O. Omare ${ }^{1,2} \cdot$ Joshua K. Kibet $^{3}$ (D) Jackson K. Cherutoi ${ }^{1,2} \cdot$ Fredrick O. Kengara $^{1,2,4}$ (D)
}

Received: 26 May 2020 / Accepted: 20 November 2020 / Published online: 6 January 2021

(C) Springer-Verlag GmbH Germany, part of Springer Nature 2021

\begin{abstract}
Aim The economic burden caused by death and disease in the world is credited mainly to tobacco use - currently linked to approximately $8,000,000$ deaths per year with approximately $80 \%$ of these faralities reported in low and middle income economies. The World Health Organization (WHO) estimates that nearly 7,000,000 deaths are attributed to direct tobacco use, while approximately 1,200,000 non-smokers exposed to second hand cigarette smoke die every year. Accordingly, tobacco use is a major threat to the public health infrastructure; therefore, proper cessation interventions must be put in place to curb tobacco abuse and ease economic and social burdens caused by the tobacco epidemic.

Methods A systematic review was conducted to investigate how scientific efforts have been advanced towards harm reduction among smokers and non-smokers. Relevant articles published during the period 2010-2020 in PubMed, Crossref, Google scholar, and Web of Science were used in this study. The articles were selected based on health impacts of cigarette smoking, tobacco cessation and emerging diseases, including Covid-19. Various cessation strategies have been identified although their efficiency is yet to match the desired results.

Results A series of carcinogenic chemicals are generated during cigarette smoking resulting in serious health complications such as cancer and mutagenesis. The precursors for tobacco induced diseases are toxic and carcinogenic chemicals of the nitrosamine type, aldehydes, polonium-210 and benzo[a]pyrene, which bio-accumulate in the body system during cigarette smoking to cause disease. Rehabilitation facilities, use of drugs to diminish the desire to smoke, heavy taxation of tobacco products and warning labels on cigarettes are some of the cessation strategies employed towards curbing tobacco abuse.

Conclusion The need for further research to develop better methods and research based policies for safe cigarette smoking and workable cessation strategies must be a priority in order to deal with the tobacco epidemic. Campaigns to promote tobacco cessation and abstinence are recommended in this review as a sure measure to mitigate against the deleterious impacts caused by cigarette smoking and tobacco abuse.
\end{abstract}

Keywords Tobacco toxicity $\cdot$ Tobacco chemicals $\cdot$ Smoking cessation $\cdot$ Covid-19

\section{Introduction}

Tobacco is one of the most notoriously abused drug substance among the rural and urban populations in the developing world - a pattern which may also be replicated across

Joshua K. Kibet

jkibet@egerton.ac.ke

Micah O. Omare

omarmitmicah@gmail.com

Jackson K. Cherutoi

cherutoijackson@yahoo.com

Fredrick O. Kengara

fkengara@maseno.ac.ke developed countries (Vellios et al. 2018). The National Institute on Drug Abuse (NIDA) of the United States of America approximates the cost of tobacco abuse, alcohol and banned drugs to be a costly undertaking in terms of crime, lost productivity and health care which is estimated to cost

1 Department of Physical and Biological Sciences, Moi University, P.O Box 3900, Eldoret 30100, Kenya

2 Africa Center of Excellence II in Phytochemicals, Textiles and Renewable Energy (ACE II PTRE), Moi University, P.O. Box 3900-30100, Eldoret, Kenya

3 Department of Chemistry, Egerton University, P.O Box 536-20115, Egerton, Kenya

4 Department of Chemistry, Maseno University, Private Bag, Maseno, Kenya 
approximately $5 \%$ of the US gross domestic product (GDP) (NIDA 2020). Globally, a steady increase in the rate of consumption of tobacco products and the number of smokers in the past decade has been reported (Mishra et al. 2016; O'Connor et al. 2020). As a result, this trend has triggered serious concerns regarding cessation on the abuse of illegal drugs and cigarette smoking which is potentially harmful to human health. Cigarette smoking has been clearly established as a risk factor for various degenerative diseases such as lung cancer and cardiovascular diseases by various scientific and epidemiological surveys (Jha 2020; Omari et al. 2015). Nonetheless, tobacco cigarette smokers are believed to be highly susceptible to the novel respiratory disease, Covid19 , given that smoke from cigarettes is a precursor for alterations on the angiotensin converting enzyme-2 (ACE-2) receptor for severe acute respiratory syndrome coronavirus-2 (SARS-CoV-2) (Brake et al. 2020). Consequently, the World Health Organization (WHO) has been on the forefront to educate the public worldwide on the dangers of tobacco use, which forms the basis of its Framework Convention on Tobacco Control (FCTC) guidelines (WHO 2019). In this review, scientific efforts directed towards the cessation of tobacco smoking and the perceived harm and impacts arising from the frequent use of this psychoactive drug are assessed by reviewing selected published articles from different journals and databases. The emerging chemicals from tobacco cigarette smoke and scientific efforts taken in order to reduce emitted toxins; use of catalysts, tobacco additives, temperature variations, heat not burn cigarettes, e-cigarettes, and other methods have been evaluated towards harm reduction. Findings from this review may direct further research in devising methods that can enhance cessation of cigarette smoking thereby promoting the healthy livelihood of cigarette smokers, and non-cigarette smokers who conventionally suffer from the effects of sidestream smoke. For the record, this work has considered literature that is published in the English language only. After the search on the multidisciplinary databases and google scholar, a number of published reports on the subject of interest, especially tobacco cigarettes smoking, toxicity and Covid-19, and carcinogenicity, were the primary focus of this review.

\section{Methodology}

A detailed literature search was conducted in PubMed, Google scholar, and scientific electronic libraries online from Jan 2020 to April 2020 in line with the procedures described in previous literature review study protocols (Palmatier et al. 2018). The literature search was self-sufficiently done in a selection of databases that comprised original published articles in peer-reviewed journals, patents, books, dissertations, and reports that addressed tobacco abuse. Accordingly, articles published between January 2012 and April 2020 were considered if they had information about tobacco ailments, such as respiratory diseases; asthma and emphysema. For search precision, information used in this work was picked from the google search engine by including general terms such as tobacco toxicity, cancer, and carcinogenicity, dangers, intake methods, throat cancer, smoking, cigarettes, SARSCoV-2, Covid-19 vulnerability, and smoking cessation. The authors set the online databases to give notifications of search outputs that contained information relevant and matching the established search standards such as academia, science direct, Mendeley, and google scholar, which were saved on personal computers (PCs) for further reading and analysis.

\section{Results and discussions}

\section{Tobacco use as a precursor for cancer}

Cigarette smoking is a well-established leading cause for cancer and mutagenesis, and the determinant factors are the duration of smoking, and the number of cigarettes smoked, which precipitate the risk for histologic types of lung cancer: squamous cell carcinoma, small cell carcinoma, adenocarcinoma, and large cell carcinoma (Babalık et al. 2018). Therefore, cigarette smoking is a precursor for transitional cell carcinomas of the bladder, ureter, and renal pelvis (Arora et al. 2018; Soliman 2018; Wojtczyk-Miaskowska and Schlichtholz 2019). Furthermore, cigarette smoke is known to raise the risk of sinonasal and nasopharyngeal cancer (Miligi et al. 2020). In addition, oropharyngeal and hypopharyngeal cancer have also been reported to be initiated by cigarette smoking (Liao et al. 2018). Additionally, liver cancer can be induced by cigarette smoking (Petrick et al. 2018). Therefore, most cancers are initiated by the carcinogenic chemicals present in cigarette smoke; the most common type of cancer being adenocarcinoma (Coleman et al. 2018).

Conventionally, tobacco can be used as either smoked tobacco or smokeless tobacco. When smoked, tobacco cigarettes emit smoke that has been linked to lung related deaths as evidenced by a number of scientific studies that emphasize that burning cigarettes release numerous chemicals that are biologically detrimental (Coleman et al. 2018; Shihadeh et al. 2015). Smoked tobacco products include but not limited to cigarettes, water pipes (Shihadeh et al. 2015), electronic cigarettes (Smith 2019), bidis, and krekets (Mishra et al. 2016). Alternatively, when tobacco is consumed in other forms apart from smoking, it consequently constitutes smokeless tobacco products such as loosely chewed tobacco leaves, snus, naswar, gutka snuffs, and tobacco paste (Hajek et al. 2019; Khan et al. 2019; Kindvall et al. 2019; Mohapatra 2019). Scientific analysis on these smokeless tobacco products have unraveled more than 20 chemical compounds 
known to be cancer causing agents, which include tobaccospecific nitrosamines, $\mathrm{N}$-nitrosamine acids, volatile $\mathrm{N}$-nitrosamines, polycyclic aromatic hydrocarbons, and aldehydes (McAdam et al. 2013; Warnakulasuriya and Straif 2018). The methods of tobacco intake and popularity trends are illustrated in Table 1.

Loose leaf tobacco chewing is prepared from tobacco leaves that are air cured, crushed, and a flavoring agent added to improve its taste (Stepanov et al. 2014). On the other hand, moist snuff, snus, consist of fire and air-cured dark tobacco, while dry snuff comprises fermented and fire cured powder (Kindvall et al. 2019; Pillitteri et al. 2020). Apparently, the main motivating factor for an individual to use tobacco products is nicotine - a tobacco alkaloid constituting nearly $95 \%$ of tobacco chemicals (Ji et al. 2017; McKinney and Vansickel 2016). When tobacco enters the human biological system in the form of smoke, numerous compounds constituting tobacco smoke are taken in by the smoker (Tsai et al. 2018), which are initiators for generative and degenerative diseases including cancer and grave respiratory diseases, such as emphysema, asthma, cardio obstructive pulmonary disorder (COPD) (Ferrante and Conti 2017).

Tobacco smoke chemistry has been the subject of extensive investigation by various scientific research authorities and individual researchers for over a century (McAdam et al. 2016) and to date, over 7000 compounds have been established to be present in tobacco smoke, with more than 50 of these chemicals identified as carcinogenic by IARC (Warnakulasuriya and Straif 2018; Weng et al. 2018). During tobacco burning, compounds including carbon monoxide, benzene, formaldehyde, polycyclic aromatic hydrocarbons (PAHs), hydrogen cyanide, and nitrosamines are produced (Morgan et al. 2017; Nlemedim 2017). In the process, incomplete combustion reactions occur at the core of the burning cigarette which consequently results in the production of PAHs (Nlemedim 2017; Weng et al. 2018).

Tobacco effluents possesses toxic, mutagenic, and carcinogenic properties because they are extremely lipid soluble
(Barnes et al. 2018), and therefore spontaneously adsorbed in the gastrointestinal tract in humans (Warnakulasuriya and Straif 2018). In addition, PAHs are rapidly distributed in the human biological tissues and deposited in fats where they bind to the DNA consequently initiating a series of disruptive effects that often end up as tumor progenitors (Warnakulasuriya and Straif 2018; Weng et al. 2018). For this reason, PAHs are listed among the highly human health threatening chemicals with a high potency that usually leads to cancer among the cigarette smoking community (Hecht 2012). Besides, PAHs have been reported to cause several other toxicological expressions in humans that include but are not limited to engorged liver with cell oedema and congestion of the liver connective tissues and blood vessels, loss in body weight, intoxication of male and female genital system, uterus development retardation, learning and lowered intelligent quotient (IQ), oocyte damage, and kidney cell infection (McAdam et al. 2016; O'Brien et al. 2016).

Some compounds, including tobacco specific nitrosamines (TSNAs) and nicotine, occur naturally in tobacco and are released during tobacco burning (Edwards et al. 2017; Konstantinou et al. 2018). Nicotine predominantly present in tobacco mainly exists in two forms - protonated nicotine and non-protonated nicotine - that are $\mathrm{pH}$ dependent (El-Hellani et al. 2015). Non-protonated nicotine is a free base and the more addictive form of nicotine, which is extremely bioavailable and freely absorbed into the blood system and is responsible for the pleasurable psychoactive effects (O'Connor et al. 2020). Scientifically, TSNAs have been recognized as the chief cancer causing agents in both smoked and smokeless tobacco (O'Connor et al. 2020; Xue et al. 2014). Tobacco is known to consist of four principle TSNA chemicals: Nnitrosonornicotine (NNN), 4-methyl-N-nitrosamino-1-(3-pyridyl)-1-butanone (NNK), N-nitrosoanatabine (NAT), and Nnitrosoanabasine (NAB) (Xue et al. 2014). Of these four, IARC marks NNN and NNK as the key cancer initiating agents in tobacco (Singhavi et al. 2018; Zamora and Hidalgo 2020). Nitrosamines form when secondary and tertiary amines

Table 1 Tobacco consumption methods and popularity trends

\begin{tabular}{lllll}
\hline Market product & Method of intake & Popularity percentage & Trend in the past two decades & References \\
\hline smoked tobacco & cigarettes & $83 \%$ & increase & Mishra et al. 2016 \\
& bidis & $13 \%$ & decrease & Mishra et al. 2016 \\
& krekets & $10 \%$ & decrease & Mishra et al. 2016 \\
& water pipes & $38 \%$ & increase & Shihadeh et al. 2015 \\
smokeless tobacco & & & & decrease \\
loose leaf chewing & mouth chewing & $35 \%$ & increase & Kindvall et al. 2019 \\
moist snuf (snus) & pinch put between gingival and buccal mucosa & $77 \%$ & decrease & Kindvall et al. 2019 \\
dry snuf & nasal inhalation & $60 \%$ & increase & Hajek et al. 2019 \\
e-cigarettes & nasal inhalation & $80 \%$ & &
\end{tabular}


react with nitriles to yield nitrosamine out of which over 70 nitrosamines have been confirmed scientifically as carcinogenic (Gunduz et al. 2016). Nitrosation of secondary amines is a very fast reaction process in which the hydrogen attached to the nitrogen is replaced by the -NO group in significantly high yields, although on the other hand, nitrosation of the tertiary amines is a slow process (Spahr et al. 2017). Therefore, nitrosation of secondary amines (nornicotine, anabasine, and anatabine) leads to the formation of tobacco explicit nitrosamines NNN, NAB, and NAT, while nornicotine, anabasine, and anatabine form part of the important alkaloids in tobacco (Cai et al. 2016). Nitrosation of tertiary amines nicotine yields NNN, which together with nicotine-derived NNK, have been identified to be strong carcinogens that have the potential to induce malignant and nonmalignant tumors in humans depending on the route of administration or ingestion (De Flora et al. 2016). Fresh tobacco leaves contain low levels of TSNAs but the levels of these chemicals increase during tobacco curing (Wang et al. 2017). Accordingly, during cigarette smoking $\mathrm{N}$ nitrosamines enters the smokers' body system through inhalation of mainstream cigarette smoke and/or side stream cigarette smoke (Gunduz et al. 2016; Hang et al. 2018). As a result, both active smokers and passive smokers become vulnerable to nitrosamines that endogenously form from uptake of alkaloids and nitrogen oxides or nitriles (Barnes et al. 2018; Wang et al. 2017). Other cancer causing agents in tobacco smoke include benzo(a)pyrene (BaP), polonium-210, and cadmium (Omari et al. 2015; Shafik et al. 2019; IARC 2019). BaP has been classified by IARC as a group $2 \mathrm{~A}$ cancer causing chemical and is therefore a risk chemical (IARC 2019; Vu et al. 2015The introduction of electronic cigarettes was supposed to promise safer cigarettes suggested to deliver low nicotine levels (Carlsen and Skjerven 2018; Hajek et al. 2019). Contrary to this proposition, scientific research on the dangers of e-cigarettes has revealed that they are more toxic and yield potentially carcinogenic chemicals formed during the use of e-cigarettes (Armendáriz-Castillo et al. 2019), Table 2. A number of compounds released from e-cigarettes have been reported to cause genetic mutation that subsequently leads to the growth of malignant cells and ultimately cancer (Barnes et al. 2018). Some of the molecular compounds suspected to be cancerous are presented in Fig. 1.

Accordingly, Drazen et al. (2019) asserted that there is a potential likelihood of an e-cigarette user getting addicted to nicotine because of its increased concentration as a result of more frequent vaping than regular smoking, thereby subjecting the user to grave health risks. Based on this observation, it has been pointed out that the increasing rates of e-cigarette use among the youth, who are considered the major consumers of e-cigarette, can be credited to the highly addictive nature of nicotine, which has the capacity to cause a public health crisis, at least, according to scientific surveys (Kurgat et al. 2016;
Singh et al. 2020). Aromatic amines, aldehydes, phenolic compounds, volatile hydrocarbons, nitro hydrocarbons, and various organic compounds present in tobacco smoke have also been proven carcinogenic through experimental studies on animals (CDC 2010; Zamora and Hidalgo 2020). IARC has classified these chemicals as group $2 \mathrm{~B}$, which are possibly carcinogenic to human beings, group $2 \mathrm{~A}$, which are probably carcinogenic to humans or group 1 , which are carcinogenic to humans (IARC 2019; CDC 2010). Additionally, it has long been reported that benzene, toluene, furan, 2-methylfuran, and isobutylene are some of the components of gas-phase cigarette smoke considered detrimental to cigarette smokers (Hang et al. 2018; Sleiman et al. 2014). Nevertheless, these compounds are sighted as potential leads in initiating lung cancer (Warden et al. 2018). However, there is limited information documented in literature regarding their cancer causing mechanisms (Hang et al. 2018).

\section{Emerging potent tobacco chemicals}

Numerous scientific researchers have identified the chemical composition of tobacco smoke with significant efforts invested on establishing the suspected carcinogens and their connection between cigarette smoking and the associated adverse health effects (Armendáriz-Castillo et al. 2019; McAdam et al. 2018). Additionally, active chemical species predominantly present in cigarette smoke include hydroxyl radicals, hydrogen peroxide, and superoxide anion radicals, which are mostly generated during the tobacco burning (Assaf et al. 2016). Therefore, environmentally persistent free radicals are a subject of great interest in research with more focus being emphasized on the formation mechanisms and their related effects on human health. Free radicals have a major contribution to impairing the respiratory landscape by majorly causing chronic cardiopulmonary dysfunction owing to the fact that they can trigger the generation of reactive oxygen species (ROS) and are well-established precursors for oxidative stress and cardiac arrest (Panth et al. 2016).

Heterocyclic hydrocarbons have been reported to be predominantly present in cigarette smoke (Barnes et al. 2018). During the thermal degradation of tobacco biomass, dibenzofuran and their associated dioxins in their polychlorinated notoriously very toxic forms are produced (Rehman et al. 2019). On the other hand, furan can be classified as an endocrine disrupting chemical given that it has a higher ability to alter animal physiology by disrupting hormonal levels (Ferreira et al. 2019). During organ development, if organisms are exposed to endocrine disrupting chemicals, such as furan $\left(\mathrm{C}_{4} \mathrm{H}_{4} \mathrm{O}\right)$, they cause irreversible damage to the hormonal profile (Grill et al. 2015; Rehman et al. 2019). Therefore, furans can have highly devastating biological organizational effects on the developing fetus if exposed to cigarette smoke during pregnancy (Horinouchi et al. 2016; Rehman et al. 2019). 
Table 2 Some carcinogenic chemicals reported in tobacco smoke

\begin{tabular}{|c|c|c|}
\hline Tobacco chemicals & Carcinogenicity level & Reference \\
\hline carbon monoxide & group 1 & IARC 2013 \\
\hline benzene & group 1 & Loomis et al. 2017 \\
\hline formaldehyde & group 1 & d'Ettorre et al. 2017 \\
\hline polycyclic aromatic hydrocarbons (PAHs) & group 1 , group $2 \mathrm{~A}$, and group 2B & ARC 2010 \\
\hline hydrogen cyanide & not listed & \\
\hline lead & group 2B & Bjurlin et al. 2020 \\
\hline tobacco specific nitrosamines (TSNAs) & group 1 & Bjurlin et al. 2020 \\
\hline nicotine & not listed & \\
\hline benzo(a)pyrene (BaP) & group 1 & Santonicola et al. 2017 \\
\hline polonium-210 & group 1 & Stanfill 2020 \\
\hline cadmium & group 1 & Stanfill 2020 \\
\hline heterocyclic aromatic amines & group $2 \mathrm{~A}$ & Bjurlin et al. 2020 \\
\hline aldehydes & group 2B & \\
\hline phenolic compounds & not listed & \\
\hline volatile hydrocarbons & group 1 & IARC 2019 \\
\hline nitro hydrocarbons & not listed & \\
\hline toluene & group 2A & Warden et al. 2018 \\
\hline furan & group 2A & IARC 2019 \\
\hline 2-methylfuran & group 2B & IARC 2019 \\
\hline
\end{tabular}

Research conducted on heterocyclic aromatic compounds has revealed that they contribute to bacterial mutagenicity (Roemer et al. 2016). These compounds form through the conventional milliard reactions involving creatinine, free amino acids, and sugars (Barzegar et al. 2019; et al., 2020). For instance, heterocyclic aromatic hydrocarbons are activated metabolically by $\mathrm{N}$-hydroxylation that forms the intermediate ion arylnitrenium, and have been reported to influence DNA damage and toxicity (Barzegar et al. 2019; Chen 2020). Similarly, aldehydes, phenolic compounds, volatile hydrocarbons, and nitro hydrocarbons are reported to be predominantly present in cigarette smoke in various concentration levels (CDC et al. 2010).

In one survey, it was reported that aldehydes can potentially undergo chemical reactions involving nucleophilic targets in body cells, lipids, and proteins and consequently form stable and unstable adducts (Sapkota and Wyatt 2015). Accordingly, pathological injuries in human beings are initiated in the lungs due to alterations of cellular functions in addition to damaged proteins, nucleic acids, and lipids thereby
Fig. 1 Tobacco specific nitrosamines identified from ecigarettes (IARC 2019)<smiles>O=NN1CCC[C@H]1c1cccnc1</smiles>

$\mathrm{N}$-nitrosonornicotine<smiles>O=NN1CC=CCC1c1cccnc1</smiles>

N-nitrosoanatabine<smiles>CN(CCCC(=O)c1cccnc1)N=O</smiles>

4-methyl-N-nitrosamino-1-(3-pyridyl)-1-butanone<smiles>O=NN1CCCCC1c1cccnc1</smiles>

N-nitrosoanabasine 
propagating vascular diseases (Phaniendra et al. 2015). Lately, there have been attempts to explore methods in which tobacco toxins can be reduced or destroyed during cigarette burning because of the observed reluctance in the smoking population to quit smoking, and the opposition of tobacco processing companies to adopt technologies that would lower harm as a result of cigarette use (Peeters and Gilmore 2015). Table 2 presents selected carcinogenic chemicals classified as carcinogenic by IARC. On the other hand, Table 3 reports the health effects of a variety of chemicals released from tobacco burning.

Designing methods that can successfully reduce toxins in tobacco will offer an effective strategy in minimizing mortality and morbidity among the cigarette smoking community (Abrams et al. 2018). With respect to this proposal, heat not burn methods have been preferably considered for use in consuming tobacco products (Abrams et al. 2018; Lachenmeier et al. 2018). These techniques involve inserting tobacco products into a tobacco heating system where they are heated at temperatures below the cigarette combustion temperatures as opposed to directly burning the cigarette (Lachenmeier et al. 2018). Such techniques when employed can significantly reduce the heat created toxins in the aerosol inhaled by the cigarette smoker (Smith et al. 2016). The desire for such techniques is aimed at lowering toxicants in cigarettes hence the manufacture of electronic cigarettes (e-cigarette), which are presumed to aid tobacco cessation (Pokhrel et al. 2015).

An e-cigarette is an electric device that allows an active smoker to inhale nicotine with supposedly fewer compounds responsible for most harmful smoking effects although the possibility of forming reactive free radical species that can cause oxidative stress and cardiac arrest cannot be ruled out (Smith 2019). Ideally, e-cigarettes serve as a nicotine replacement therapy that enhances the reduction towards the desire to smoke and eventually making it easier for smokers to quit smoking but on the contrary, research survey has found this to be untrue (Kindvall et al. 2019). In operational e-cigarettes, an e-liquid is heated to produce e-vapor in the form of aerosols with flavorings and nicotine, which are consequently delivered into the smoker (DeVito and Krishnan-Sarin 2018). Even though the use of e-cigarettes is presumed to be safer compared to ordinary cigarette (Hilton et al. 2016), they have been reported to contain toxins that induce toxicity, inflammation, and oxidative stress in smokers (Dasgupta and Klein 2014), as listed in Table 3. During the use of e-cigarettes, factors leading to the synthesis of TSNAs are believed to be put under control (Farsalinos et al. 2015; Konstantinou et al. 2018). For instance, some farmers and manufacturers have employed strategies that lower the alkaloid content in tobacco in order to suppress NNN and nornicotine development given that NNN and NNK are the two TSNAs that have been classified by the IARC as carcinogenic to humans (Kumar et al. 2018). This has been achieved by removing the nitrate-reducing microbial activity, controlling the conditions of the temperature and humidity during curing, and employing heat exchange methods that lower nitrosamine concentration levels (Law et al. 2016; Riddick et al. 2017). Similarly, low yield "light" cigarettes and "ultra-light" cigarettes have been designed by different tobacco processing companies, and they are suggested to contain fewer toxins compared to the normal "heavy" cigarettes (Popova et al. 2018). Elsewhere, a study on nicotine reduction and its associated impacts has pointed out two required lines of action; preventing addiction and reduction or stoppage of tobacco consumption altogether, which never has an easy strategy towards tobacco cessation (Schmidt et al. 2018). Whereas the use of e-cigarettes and light cigarettes as alternative ways to reduce tobacco toxins may be a successful strategy, controlling thousands of other tobacco toxins released during tobacco burning cannot be achieved by these techniques, which are focused only in lowering nicotine concentration levels in a cigarette (Auer et al. 2017). Moreover, smokers may end up consuming more of these cigarettes in order to get the desired effect of smoking, leading to ingesting high levels of toxins, which may be injurious to the human biological environment (Benowitz et al. 2017; Morean et al. 2016).

Efforts have been advanced towards devising methods that can aid in lowering the concentrations of TSNAs in cigarette smoke which form as a result of microbes in tobacco decay during tobacco curing and thus produce nitrites and NOx precursors for TSNAs production when tobacco is burned (Warek et al. 2019). Further, it has been pointed out that the use of nitrite scavengers as additives can eliminate active microbes (Stanfill 2020). Accordingly, Shi and Yang (2017) have described a novel alternative technique that focuses on reducing bacteria and bacterial activities in tobacco extracts, which eventually reduce TSNAs in cigarette smoke. Furthermore, the method described by d'Ettorre et al. (2017) for the reduction of TSNAs and improving the leaf quality in tobacco during curing has been found to be effective in minimizing TSNAs health effects arising from cigarette smoking. It is important to note that tobacco soil treatment and spraying of tobacco plants prior to harvesting stimulates antioxidant production that interferes with the formation of TSNAs during curing ( $\mathrm{Li}$ et al. 2008). In addition, the use of filters that can selectively remove TSNAs from cigarettes smoke has been suggested ( $\mathrm{Li}$ et al. 2018) but still found to be ineffective especially in removing carbon monoxide to any acceptable degree. Because TSNAs are produced during curing and fermentation processes, an alternative method such as pasteurization of snus can be employed to produce tobacco products of minimal harm (Stanfill 2020).

Furthermore, a review on the interventions that promote harm reduction due to continued tobacco use is important in quitting cigarette smoking (Lindson-Hawley et al. 2016). The associated dangers of smoking can also be minimized by 
Table 3 Chemicals present in e-cigarettes and their associated health effects (Armendáriz-Castillo et al. 2019; IARC 2019)

\begin{tabular}{|c|c|c|}
\hline Name & Health effects & $\begin{array}{l}\text { Carcinogenic } \\
\text { potential }\end{array}$ \\
\hline$(+)$-aromadendrene & cytotoxic/skin irritation & unknown \\
\hline (z)-3-hexen-1-ol & eye irritation & unknown \\
\hline 1-methyl phenanthrene & cytotoxic/eye irritation/skin irritation & group 3 \\
\hline 1,3-butanediol & low concern based on experimental and modeled data & unknown \\
\hline 1,3-propanediol & not a significant hazard via inhalation of either the gas phase or a gas/aerosol mixture & unknown \\
\hline 2-acetylpyrrole & skin irritation & unknown \\
\hline 2,3-dimethylpyrazine & cytotoxic & unknown \\
\hline 2,3-pentanedione & skin irritation/eye irritation/systemic organ irritation & unknown \\
\hline 2,3,5-trimethylpyrazine & cytotoxic & unknown \\
\hline 3-methyl-1-butanol & cytotoxic/skin irritation/eye irritation/respiratory tract irritation & unknown \\
\hline acetic acid & respiratory tract irritation & unknown \\
\hline benzyl acetate & cytotoxic/eye irritation/respiratory tract irritation & group 3 \\
\hline benzyl alcohol & cytotoxic & unknown \\
\hline butyl butyrate & eye irritation/mild effects/behavioral Effects & unknown \\
\hline camphor & cytotoxic/neurotoxic/systemic organ irritation/mild effects/ behavioral effects & unknown \\
\hline cinnamaldehyde & eye irritation/respiratory tract irritation/systemic organ irritation & \\
\hline cinnamyl alcohol & unknown effects in human health & group 2B \\
\hline coumarin & behavioral effects/systemic organ irritation & group 3 \\
\hline methyl cyclopentenolone & unknown effects in human health & \\
\hline diacetyl & eye irritation/skin irritation & group 3 \\
\hline diethylene glycol & systemic organ irritation/ skin irritation & \\
\hline ethylbutyrate & mild effects/behavioral effects & \\
\hline ethylmaltol & cytotoxic & unknown \\
\hline ethylvanillin & unknown effects in human heal & unknown \\
\hline ethylene glycol & harmful effects in animal model & unknown \\
\hline glycerin & eye irritation/skin irritation/respiratory tract irritation & unknown \\
\hline hydroxyacetone & cytotoxic & group 2B \\
\hline i-butyric acid & respiratory tract irritation & \\
\hline isobutyl acetate & eye irritation/skin irritation/respiratory tract irritation/mild effects & group 2B \\
\hline isoamyl acetate & eye irritation/skin irritation/respiratory tract irritation & unknown \\
\hline isopentyl isovalerate & harmful effects in animal models & unknown \\
\hline 1-menthyl acetate & respiratory tract irritation & unknown \\
\hline limonene & no evidence of carcinogenic activity in rats or human & unknown \\
\hline maltol & cytotoxic & unknown \\
\hline menthone & harmful effects in animal models & unknown \\
\hline methylanthranilate & unknown effects in human health & group 2B \\
\hline methylcinnamate & unknown effects in human health & unknown \\
\hline methylsalicylate & neurotoxin/cardiovascular effects & unknown \\
\hline myosmine & carcinogenic & group 2B \\
\hline n-hexanol & harmful effects in animal models & group 2B \\
\hline nicotyrine & unknown effects in human health & \\
\hline o-tolualdehyde & harmful effects in animal models/unknown effects in human health & unknown \\
\hline p-cymene & skin irritation/mild effects & group 2B \\
\hline propylene glycol & respiratory tract irritation & unknown \\
\hline safrole & harmful effects in animal models & group 2B \\
\hline thujone (sum of $\alpha$ - and $\beta$-diastereomers) & harmful effects in animal models & unknown \\
\hline trans-2-hexen-1-ol & unknown effects in human health & unknown \\
\hline vanillin & cytotoxic & unknown \\
\hline
\end{tabular}


Table 3 (continued)

\begin{tabular}{|c|c|c|}
\hline Name & Health effects & $\begin{array}{l}\text { Carcinogenic } \\
\text { potential }\end{array}$ \\
\hline$\beta$-damascone & skin irritation & group 3 \\
\hline$\gamma$-decalactone & respiratory tract irritation & unknown \\
\hline
\end{tabular}

lowering the number of cigarettes smoked daily or consuming alternative tobacco products such as chewing tobacco or snus which constitute the necessary tobacco replacement therapy (Lindson-Hawley et al. 2016). The use of pharmaceuticals, including bupropion and varenicline, has also been evaluated to be helpful in reducing tobacco toxins (Jiloha 2014; Prochaska and Benowitz 2019), although there is a lack of precise evidence on their workability. For this reason, the use of smokeless tobacco products has been highly recommended as an alternative route to smoking on the argument that they are low tar yielding and presumably safer (Drazen et al. 2019). On the contrary, a number of chemicals have been identified (IARC 2019; Kumar et al. 2018), as listed in Table 4, and IARC has classified these chemicals as carcinogenic.

Accordingly, even though the use of smokeless tobacco products is regarded as an alternative to reducing nicotine toxicology and their related risks in human health, the identification of these carcinogens in smokeless tobacco products renders them more dangerous to the cigarette smoking population (Lee et al. 2016). Meanwhile, a lack of policies for regulation and monitoring of the concentrations of chemicals in commercially available smokeless tobacco products may be considered as the major reason for quality control failures (Kumar et al. 2018). In order to address these challenges, efforts have been invested by relevant drug regulating authorities in many countries worldwide to evaluate the contents of these chemicals in tobacco and cigarettes before releasing a tobacco product into the market (Wright 2015).

\section{The consequences of tobacco abuse}

According to Mallock et al. (2018), cigarette smoke is highly toxic due to the generation of poisonous pyrolysis products during burning. For instance, a study carried out by Ivashynka et al. (2019) explored the effects of cigarette smoking and determined that it led to increased heart beat and a corresponding increase in blood pressure. Moreover, maternal smoking has been associated with decrease in intelligence test performance, poor cognitive achievements, memory impairment, hyperactivity and weak attention span (Kristjansson et al. 2018). Evidently from previous studies, ageing in humans has been linked to repeated inhalation of smoke from cigarettes during passive and active smoking (MacNee et al. 2014). Accordingly, smoking decreases biological ageing to approximately 55 years, especially among women (Skjodt et al. 2018). Subsequently, substance smoking speeds up the normal ageing process of the cigarette smoker's skin, contributing to wrinkles and loss of skin's aesthetic value and beauty (Clatici et al. 2017). These effects are prone to occur to a smoker after a period of about 10 years or less depending on the number of cigarettes an individual smokes, and the longer the smoking period (Fatani et al. 2020; Osman et al. 2017. Notably, earlier skin damage as a result of smoking can be manifested on the smoker, but it is difficult for one to observe them immediately (Clatici et al. 2017). Moreover, facial wrinkles in human beings can be strongly projected from cigarette smoking and these can be attributed essentially to nicotine uptake, which causes thinning of blood vessels on the outermost skin layer, thereby impairing blood flow to the skin (Benowitz and Burbank 2016). As a result, the skin is starved of oxygen and nutrients, including vitamin A (Clatici et al. 2017). Moreover, fibers such as collagen and elastin, which are responsible for skin strength and elasticity, are destroyed by more than 7000 chemicals in tobacco smoke leading to skin sagging and premature wrinkles and haggard looks (Skjodt et al. 2018).

Additionally, scientific studies have reported the occurrence of chronic coughs and tuberculosis cases ignited by cigarette smoking, implying that increased tobacco consumption rates and exposure to second hand tobacco smoke promotes the risk of tuberculosis and death (Bisallah et al. 2018). Furthermore, coughs can serve as the first signature in cigarettes smokers of a respiratory concern (Ashok et al. 2017). The harmful effects of cigarette smoking are greatly magnified by HIV infected individuals who continue to smoke even when the disease is under control as a result of medication (Popova et al. 2018). More disturbing is that these groups of people lose more years of life to cigarette smoking than the disease itself since, other than the adverse health effects of smoking, cigarette smoking exposes HIV-positive individuals to threats for a host of grave HIV associated comorbidities and untimely deaths (Giles et al. 2018).

Nicotine addiction among the cigarette smoking community is a severe public health concern worldwide due to the genetic factors that contribute to disease vulnerability, and which also result in brain disorders and other harmful effects 
Table 4 Chemicals in smokeless tobacco and their IARC classification (IARC 2019)

\begin{tabular}{|c|c|c|c|}
\hline Tobacco chemical & IARC classification & Tobacco chemical & IARC classification \\
\hline $\mathrm{NNN}$ & 1 & chlordane & $2 \mathrm{~B}$ \\
\hline NNK & 1 & heptachlor & 2B \\
\hline benzo (a)pyrene & 1 & 3-(methylnitrosamino)-propionitrile & $2 \mathrm{~B}$ \\
\hline formaldehyde & 1 & cobalt & $2 \mathrm{~B}$ \\
\hline beryllium & 1 & ochratoxin A & $2 \mathrm{~B}$ \\
\hline arsenic & 1 & aflatoxin M1 & 2B \\
\hline cadmium & 1 & lead & 2B \\
\hline $\mathrm{N}$-nitrosodimethylamine & $2 \mathrm{~A}$ & NAT & 3 \\
\hline nitrosoacids (NA) & $2 \mathrm{~A}$ & NAB & 3 \\
\hline dibenz[a,h]anthracene & $2 \mathrm{~A}$ & $\mathrm{~N}$-nitrosoproline & 3 \\
\hline dichlorodiphenyltrichloroethane & $2 \mathrm{~A}$ & N-hydroxyproline & 3 \\
\hline nitrate & $2 \mathrm{~A}$ & 3-(n-nitrosomethylamino)-propionaldehyde & 3 \\
\hline nitrite & $2 \mathrm{~A}$ & benzo[e]pyrene & 3 \\
\hline hydrazine & $2 \mathrm{~A}$ & triphenylene & 3 \\
\hline ethyl carbamate & $2 \mathrm{~A}$ & pyrene & 3 \\
\hline n-nitrosodiethanolamine & $2 \mathrm{~B}$ & fluoranthene & 3 \\
\hline N-nitrososarcosine (NSAR) & 2B & acenaphthene & 3 \\
\hline N-nitrosoethylmethylamine & 2B & fluorene & 3 \\
\hline $\mathrm{N}$-nitrosopyrrolidine & 2B & phenanthrene & 3 \\
\hline N-nitrosopiperidine & 2B & anthracene & 3 \\
\hline n-nitrosomorpholine & 2B & benzo[g,h,i]perylene & 3 \\
\hline $\mathrm{N}$-nitrosodiethanolamine & $2 \mathrm{~B}$ & crotonaldehyde & 3 \\
\hline benz[a]anthracene & $2 \mathrm{~B}$ & acrolein & 3 \\
\hline chrysene & $2 \mathrm{~B}$ & endrin & 3 \\
\hline benzoflouranthene (j) & $2 \mathrm{~B}$ & maleic hydrazine & 3 \\
\hline indeno[1,2,3-cd]pyrene & $2 \mathrm{~B}$ & Natural gas liquids & 3 \\
\hline 5-methylcytosine & $2 \mathrm{~B}$ & n-nitrosoguvacine & 3 \\
\hline naphthalene & $2 \mathrm{~B}$ & euginol & 3 \\
\hline benzo[b]fluoranthene & $2 \mathrm{~B}$ & chromium & 3 \\
\hline benzo[k]fluoranthene & $2 \mathrm{~B}$ & mercury & 3 \\
\hline dibenzo[a,i]pyrene & $2 \mathrm{~B}$ & quercetin & 3 \\
\hline acetaldehyde & $2 \mathrm{~B}$ & morpholine & 3 \\
\hline
\end{tabular}

to the individual and economic burden to the society at large (Ji et al. 2017). Chromosomal complications arise as a result of harboring risk genes for addiction to various toxic compounds in cigarette smoke (Li and Burmeister 2009). As per studies performed for numerous addiction phenotypes, a prediction for linkage regions on chromosome 11 contributions towards addictive phenotypes has been undertaken previously (Bevilacqua and Goldman 2009). Habitual smoking therefore has been linked to chromosome 11q14 and the smoking behavior associated with chromosome 11q12 (Li 2018). A study by Pineles et al. (2014) determined that tobacco constituents can greatly damage the chromosomes in sperm or alter the morphological changes of the sperm, reduce the sperm density, sperm mobility and semen volume, thus affecting the male fertility capability.

\section{The epidemiological impacts of Covid-19 on cigarette smokers}

The worldwide outbreak of SARS-CoV-2, the precursor for the disease Covid-19, has been associated with more deaths among cigarette smokers compared to individuals who have never smoked (Vardavas and Nikitara 2020). Nicotine in cigarette smoke induces and causes alterations and responses in the human immune system, especially in the lungs, and thus initiates infections, allergy, tumor necrosis factor $\alpha$ - expression, mucosal inflammation, and other respiratory illnesses (Brake et al. 2020; Lippi and Henry 2020). However, contrary to this, there is no association between active smoking and the severity of Covid-19 (Lippi and Henry 2020) but a disputation of these sentiments is registered in a review study conducted 
by Vardavas and Nikitara (2020) who determined that individuals that were current smokers or former smokers exhibited severe symptoms of Covid-19 with higher chances of intensive care unit (ICU) admission in contrast with nonsmokers. Furthermore, a susceptibility analysis of Covid-19 on smokers based on ACE-2 receptors determined that the receptor expression in intrapulmonary airways and epithelial cells was higher in current smokers than former smokers, but significantly much higher than in people who have never smoked (Wang et al. 2020), therefore indicating a presumably higher probability for Covid-19 infection in smokers than individuals who have never smoked. Evidently, these observations are in agreement with findings from scientific experiments on ACE2 expression in the small airways of Covid-19 patients, for both smokers and none smokers (Leung et al. 2020). The spread of Covid-19 is greatly through contact with infected surfaces even though it is also suspected to be airborne and highly contagious. Accordingly, it can be supposed that, smokers have a possibility of contracting the SARS-Cov-2 as a result of their fingers touching the cigarette stick and successfully pass it to their mouths through the lips biting the cigar stick. More so, water pipe smoked tobacco products are commonly communal and involve mouth piece sharing and the chances of spreading SARS-Cov-2 virus cannot be ignored. Therefore, these observations among cigarette smokers can result in high cases of Covid-19 infections.

\section{Tobacco cessation strategies}

Individual smokers are likely to quit smoking by shifting to lower tar and low nicotine cigarettes that are apparently less harmful or elect to use cigarettes that have reduced toxicity levels such as light cigarettes (Borrelli and O'Connor 2019). In the past few years, there have been significant innovative and effective behavioral and pharmacological smoking cessation methods such as use of heat not burn cigarettes including e-cigarettes and vaping (Singh et al. 2020). A systematic review on smokers and non-smokers perceptions of visually unappealing cigarette sticks concludes that an individual's smoking behavior is influenced by the appearance of the cigarette (Drovandi et al. 2018), and therefore, normally from a marketing perspective, cigarettes may have physical attributes that are either appealing or non-appealing to consumers in terms of size, color, and health warnings written on the cigarette packs. Accordingly, a cigarette is appealing to the consumer based on visual, olfactory or other perceptual or cognitive signals that influence the user's apparent taste, smell, and chemisthetic flavor (Da Ré et al. 2018; O'Connor et al. 2020).

In order to reduce the use of tobacco products, a control technique may possibly require modifications in size, color, and written health warnings on the cigarette sticks in order to render them unappealing and hence promote negative perception in cigarette smoking (Drovandi et al. 2018). This is very important given that in terms of size; smaller diameter cigarettes have been found to be attractive to the cigarette smoking population unlike those with large diameters (Drovandi et al. 2018; Moodie et al. 2017). On the same point, brighter colored cigarettes have been reported by Drovandi et al. 2018 to be more attractive to smokers. Therefore, irrespective of health warnings being labeled on cigarettes, there are reports that they are ineffective in successfully curbing cigarette smoking because smokers tend to ignore them or find them to be irrelevant when compared to their perceived cigarette smoking "benefits" (Moodie et al. 2017). Accordingly, in order to promote and achieve further reduction in tobacco use, new and deterent warnings that include the financial consequences and impact on individual appearance can be effective in discouraging smokers and/or otherwise increase taxation on cigarettes beyond the reach of a majority of cigarette smoking community (Langley 2019; Tynan et al. 2016). Lazard et al. (2018) and colleagues have emphasized that health warnings written on cigarette packages do not discourage smoking and are therefore ineffective in promoting tobacco cessation behavior, although previous research has found this argument to be obsolete and not authoritative. Nonetheless, this is mainly important given that it provides information and reminds the smokers of the health risks associated with tobacco abuse.

The introduction of e-cigarettes has become common among the youth and it is employed as a cessation strategy aimed at assisting adult smokers to quit cigarette smoking (Singh et al. 2020). On the contrary, a statement made by Food and Drug Administration (FDA), commissioner Scott Gottlieb on the use of e-cigarettes (UFDA 2018) asserts that e-cigarettes have been assessed as the leading cause of pulmonary diseases, and projects these types of cigarettes as potentials for dire health consequences. As a rejoinder, Schier et al. (2019) and colleagues recommend that all persons should refrain from using e-cigarettes until such a time when more research-based information will be available to address the dangers e-cigarettes and their associated lung injury among other ailments.

Legislative policies that have been passed by different countries with respect to tobacco use if strictly applied can help promote tobacco cessation (Hatoun et al. 2018). These measures include the implementation of policies such as the application of huge tobacco excise taxes which may have a significant potential to reduce tobacco abuse (Tynan et al. 2016). By enforcing huge excise taxes on tobacco products, the purchase prices are raised thereby decreasing the number of consumers that can afford the commodity and hence leading to a possible reduction in cigarette smoking (Tynan et al. 2016). Cessation on cigarette smoking has also been enhanced by implementing smoke free air laws, comprehensive marketing bans, and media campaigns that have impacted greatly in the reduction of cigarette smoking (Hatoun et al. 2018). Smokers' advice to quit on medical grounds has been cited 
as a move in the right direction towards long term abstinence and opportunistic smoking cessation (Aveyard et al. 2012). Consequently, smoking cessation can be achieved through interaction with smokers by offering social and therapeutic assistance to quit smoking.

There is evidence that the use of drugs such as the antidepressant bupropion (zyban) can be helpful in cases of cigarette smoking (Reddy et al. 2020; Ng 2017). Nonetheless, research has revealed that the side effect of this drug on HIV patients because it interacts with some anti-HIV drugs such as ritonavir and efavirenz (Sustiva) to cause more health complications (Cirrincione and Scarsi 2018), and therefore this option is strongly advised against. Additionally, bupropion has been found to cause dry mouth, restlessness, insomnia, and headaches among certain users (Bhatia et al. 2017).

\section{Conclusion}

This review has highlighted the current trends in tobacco abuse and its potency as a cancer agent, emerging chemicals from tobacco smoke, efforts taken to reduce tobacco toxins, the health consequences, and epidemiological impacts of smoking on the prevalence of the novel Covid-19 pandemic. The increasing number of smokers and tobacco abuse worldwide has caused a grave concern on the associated deleterious health impacts given that there is a lack of control policies regulating and monitoring the concentrations of chemicals in commercially available smokeless tobacco products sold on the market. Accordingly, thousands of chemicals have been identified in both cigarette smoke and smokeless tobacco products and classified as carcinogenic by the International agency for research on cancer (IARC). As a result of this challenge, various methods have been suggested in order to promote "safe" smoking and minimize tobacco harm. These measures include but not limited to, the use of heat not burn cigarettes, lowering TSNAs in tobacco, use of pharmaceutical additives such as bupropion and varenicline, oleoresins and other chemical additives such as menthol, humectants and essential oils (chocolate, ginger, lavender, peppermint, vanilla, cinnamon) with the sole aim of reducing toxins and improving taste in cigarette smoking. Nevertheless, these techniques have not been effective in achieving the intended goal, and therefore, quitting cigarette smoking is suggested as the only sure option to reduce tobacco mortality and morbidity. Lately, the Covid-19 (SARS-Cov-2) pandemic has posed a serious health concern worldwide, especially for cigarette smokers whose immune system is compromised. This is likely to persist owing to the fact that there is no known definitive medication regimen designed towards countering the pandemic, at least as of the time of this review; however, several vaccines are currently being developed and tested, with distribution being planned for the near future. Various sanitation instructions have been suggested in order to help in mitigating the spread of the SARS-Cov-2 virus among the general public. On the other hand, smoking has been linked to severity of Covid-19 effects in smokers and eventually earlier stage deaths. Consequently, smoking cessation campaigns have been emphasized and include inscription of health warnings on cigarettes, laying down stringent laws prohibiting the use of tobacco products, media campaigns, use of antidepressants, and assisting smokers to quit smoking through advice and rehabilitation. Although smoking cessation has not been achieved to a significant degree, the current methods employed have proven to be quite effective.

Acknowledgements The authors are thankful to the Africa Center of Excellence II in Phytochemicals, Textiles and Renewable Energy (ACE II PTRE) - Moi University, and Egerton University, Division of Research and Extension for facilitating the success of this review article.

Authors' contributions Micah O. Omare: Formal analysis, and writing original draft. Joshua K. Kibet: Conceptualization, methodology, formal analysis, writing \& editing, validation \& supervision. Jackson K. Cherutoi: Project administration, resources, review \& editing. Fredrick O. Kengara: Writing \& editing, validation \& supervision.

Funding The authors are grateful to the Africa Center of Excellence II in Phytochemicals, Textiles and Renewable Energy (ACE II PTRE) and Egerton University grant \#EU/RE/DVC/072 for co-funding this research.

\section{Compliance with ethical standards}

Conflict of interest The authors declare no conflict of interest.

Ethical approval Not applicable.

Informed consent Not applicable.

\section{References}

Abrams DB, Glasser AM, Pearson JL, Villanti AC, Collins LK, Niaura RS (2018) Harm minimization and tobacco control: reframing societal views of nicotine use to rapidly save lives. Annu Rev Public Health 39:193-213. https://doi.org/10.1146/annurev-publhealth040617-013849

ARC (2010) Some non-heterocyclic polycyclic aromatic hydrocarbons and some related exposures. (Vol. 92). IARC Press, International Agency for Research on Cancer. (IARC Monographs on the Evaluation of Carcinogenic Risks to Humans, No. 92.). https:// www.ncbi.nlm.nih.gov/books/NBK321712/

Armendáriz-Castillo I, Guerrero S, Vera-Guapi A, Cevallos-Vilatuña T, García-Cárdenas JM, Guevara-Ramírez P et al. (2019) Genotoxic and carcinogenic potential of compounds associated with electronic cigarettes: a systematic review. Hindawi. https://doi.org/10.1155/ 2019/1386710

Arora HC, Fascelli M, Zhang JH, Isharwal S, Campbell SC (2018) Kidney, ureteral, and bladder cancer: a primer for the internist. Med Clin N 102(2):231-249. https://doi.org/10.1016/j.mcna.2017. 10.002

Ashok M, Girish R, Varsha N (2017) Know your cough: a new index to assess effects of cough severity on patient's health and overall 
symptoms-an Indian survey report. Prim Health Care 7(277):21671079. https://doi.org/10.4172/2167-1079.1000277

Assaf NW, Altarawneh M, Oluwoye I, Radny M, Lomnicki SM, Dlugogorski BZ (2016) Formation of environmentally persistent free radicals on $\alpha-\mathrm{Al} 2 \mathrm{O} 3$. Environ Sci Technol 50(20):1109411102. https://doi.org/10.1021/acs.est.6b02601

Auer R, Concha-Lozano N, Jacot-Sadowski I, Cornuz J, Berthet A (2017) Heat-not-burn tobacco cigarettes: smoke by any other name. JAMA Intern Med 177(7):1050-1052. https://doi.org/10.1001/ jamainternmed.2017.1419

Aveyard P, Begh R, Parsons A, West R (2012) Brief opportunistic smoking cessation interventions: a systematic review and metaanalysis to compare advice to quit and offer of assistance. Addiction 107(6):1066-1073. https://doi.org/10.1111/j.1360-0443. 2011.03770.x

Babalık M, Topaloğlu İ, Saltürk Z, Berkiten G, Atar Y, Tutar B et al (2018) The effects of exposure to environmental cigarette smoke on the vocal folds of rats. J Voice 32(6):652-654. https://doi.org/ 10.1016/j.jvoice.2017.09.006

Barnes JL, Zubair M, John K, Poirier MC, Martin FL (2018) Carcinogens and DNA damage. Biochem Soc Trans 46:1213-1224. https://doi. org/10.1042/BST20180519

Barzegar F, Kamankesh M, Mohammadi A (2019) Heterocyclic aromatic amines in cooked food: a review on formation, health risktoxicology and their analytical techniques. Food Chem 280:240 254. https://doi.org/10.1016/j.foodchem.2018.12.058

Benowitz NL, Burbank AD (2016) Cardiovascular toxicity of nicotine: implications for electronic cigarette use. Trends Cardiovasc Med 26(6):515-523. https://doi.org/10.1016/j.tcm.2016.03.001

Benowitz NL, Donny EC, Hatsukami DK (2017) Reduced nicotine content cigarettes, e-cigarettes and the cigarette end game. SSA 112(1): 6. https://doi.org/10.1111/add.13534

Bevilacqua L, Goldman D (2009) Genes and addictions. Clin Pharmacol Ther 85(4):359. https://doi.org/10.1038/clpt.2009.6

Bhatia SC, Petty F, Gabel T (2017) Substance and non substance related addiction disorders: diagnosis and treatment. Bentham Science, Sharjah. https://doi.org/10.2174/97816810834381170101

Bjurlin MA, Matulewicz RS, Roberts TR, Dearing BA, Schatz D, Sherman $S$ et al (2020) Carcinogen biomarkers in the urine of electronic cigarette users and implications for the development of bladder cancer: a systematic review. Eur Urol Oncol S2588-9311(20): 30029-30028. https://doi.org/10.1016/j.euo.2020.02.004

Bisallah CI, Rampal L, Sidik SM, Iliyasu Z, Lye MS, Onyilo MO (2018) Knowledge, attitude and preventive practices regarding tuberculosis and its predictors among HIV patients in general hospital, Minna, north-central, Nigeria. Mal J Med Health Sci 14(1):45-55

Borrelli B, O'Connor GT (2019) E-cigarettes to assist with smoking cessation. N Engl J Med 380(7):678-679. https://doi.org/10.1056/ NEJMe1816406

Brake SJ, Barnsley K, Lu W, McAlinden KD, Eapen MS, Sohal SS (2020) Smoking upregulates angiotensin-converting enzyme-2 receptor: a potential adhesion site for novel coronavirus SARS-CoV-2 (Covid-19). J Clin Med 9(3):E841. https://doi.org/10.3390/ jem9030841

Cai B, Ji H, Fannin FF, Bush LP (2016) Contribution of nicotine and nornicotine toward the production of $\mathrm{N}^{\prime}$-Nitrosonornicotine in aircured tobacco (Nicotiana tabacum). J Nat Prod 79(4):754-759. https://doi.org/10.1021/acs.jnatprod.5b00678

Carlsen KCL, Skjerven HO, Carlsen KH (2018) The toxicity of Ecigarettes and children's respiratory health. Paediatr Respir Rev 28:63-67. https://doi.org/10.1016/j.prrv.2018.01.002

CDC (2010) Publications and reports of the surgeon general. In: Office of the Surgeon General (Ed) How tobacco smoke causes disease: the biology and behavioral basis for smoking-attributable disease: a report of the surgeon general, Atlanta (GA): Centers for Disease
Control and Prevention (US). Retrieved from https://www.ncbi. nlm.nih.gov/pubmed/21452462

CDC, NCCDPHP, OSH (2010) How Tobacco Smoke Causes Disease: The Biology and Behavioral Basis for Smoking-Attributable Disease: A Report of the Surgeon General. Atlanta (GA): Centers for Disease Control and Prevention (US); 2010. 3, Chemistry and Toxicology of Cigarette Smoke and Biomarkers of Exposure and Harm). https://www.ncbi.nlm.nih.gov/books/NBK53014/

Chen CH (2020) Foreign compounds: foods, drugs, and other chemicals. In: Xenobiotic metabolic enzymes: bioactivation and antioxidant defense. Springer, Cham, pp 11-22. https://doi.org/10.1007/978-3030-41679-9_2

Cirrincione LR, Scarsi KK (2018) Drug interactions in HIV: nucleoside, nucleotide and nonnucleoside reverse transcriptase inhibitors and entry inhibitors. In: Drug interactions in infectious diseases: antimicrobial drug interactions. Humana, Cham, pp 297-356. https://doi. org/10.1007/978-3-319-72416-4_8

Clatici VG, Racoceanu D, Dalle C, Voicu C, Tomas-Aragones L, Marron SE et al (2017) Perceived age and life style. The specific contributions of seven factors involved in health and beauty. Maedica 12(3): 191-201

Coleman HG, Xie S-H, Lagergren J (2018) The epidemiology of esophageal adenocarcinoma. Gastroenterology 154(2):390-405. https:// doi.org/10.1053/j.gastro.2017.07.046

Da Ré AF, Gurgel LG, Buffon G, Moura WER, Marques Vidor DCG, Maahs MAP (2018) Tobacco influence on taste and smell: systematic review of the literature. Int Arch Otorhinolaryngol 22(1):81-87. https://doi.org/10.1055/s-0036-1597921

Dasgupta A, Klein K (2014) Oxidative stress caused by cigarette smoking, alcohol abuse, and drug abuse. Elservier, Sandiego, pp 59-75. https://doi.org/10.1016/B978-0-12-405872-9.00004-5

De Flora S, Ganchev G, Iltcheva M, La Maestra S, Micale RT, Steele VE et al (2016) Pharmacological modulation of lung carcinogenesis in smokers: preclinical and clinical evidence. TIPS 37(2):120-142. https://doi.org/10.1016/j.tips.2015.11.003

DeVito EE, Krishnan-Sarin S (2018) E-cigarettes: impact of E-liquid components and device characteristics on nicotine exposure. Curr Neuropharmacol 16(4):438-459. https://doi.org/10.2174/ 1570159X15666171016164430

Drazen JM, Morrissey S, Campion EW (2019) The dangerous flavors of e-cigarettes. N Engl J Med. https://doi.org/10.1056/NEJMe1900484

Drovandi A, Teague P-A, Glass B, Malau-Aduli B (2018) A systematic review of smoker and non-smoker perceptions of visually unappealing cigarette sticks. Tob Induc Dis 16. https://doi.org/10.18332/tid/ 82191

d'Ettorre G, Criscuolo M, Mazzotta M (2017) Managing formaldehyde indoor pollution in anatomy pathology departments. IOS Press, 56(3):397-402. https://doi.org/10.3233/WOR-172505

Edwards SH, Rossiter LM, Taylor KM, Holman MR, Zhang L, Ding YS et al (2017) Tobacco-specific nitrosamines in the tobacco and mainstream smoke of US commercial cigarettes. Chem Res Toxicol 30(2):540-551. https://doi.org/10.1021/acs.chemrestox.6b00268

El-Hellani A, El-Hage R, Baalbaki R, Salman R, Talih S, Shihadeh A et al (2015) Free-base and protonated nicotine in electronic cigarette liquids and aerosols. Chem Res Toxicol 28(8):1532-1537. https://doi. org/10.1021/acs.chemrestox.5b00107

Farsalinos KE, Gillman G, Poulas K, Voudris V (2015) Tobacco-specific nitrosamines in electronic cigarettes: comparison between liquid and aerosol levels. Int J Environ Res Public Health 12(8):9046-9053. https://doi.org/10.3390/ijerph120809046

Fatani AZ, Alshamrani HM, Alshehri KA, Almaghrabi AY, Alzahrani YA, Abduljabbar MH (2020) Awareness on the association between skin aging and smoking: impact on smoking quitting. Imam J Appl Sci 5(1):33. https://doi.org/10.4103/ijas.ijas_17_19 
Ferrante M, Conti GO (2017) Environment and neurodegenerative diseases: an update on miRNA role. Microrna 6(3):157-165. https:// doi.org/10.2174/2211536606666170811151503

Ferreira IM, Pinho O, Petisca C (2019) Potential effects of furan and related compounds on HealthCoffee, pp 520-540. https://doi.org/ $10.1039 / 9781788015028-00520$

Giles ML, Gartner C, Boyd MA (2018) Smoking and HIV: what are the risks and what harm reduction strategies do we have at our disposal? AIDS Res Ther 15(1):26. https://doi.org/10.1186/s12981-0180213-Z

Grill AE, Schmitt T, Gates LA, Lu D, Bandyopadhyay D, Yuan JM, Murphy SE, Peterson LA (2015) Abundant rodent furan-derived urinary metabolites are associated with tobacco smoke exposure in humans. Chem Res Toxicol 28:1508-1516. https://doi.org/10.1021/ acs.chemrestox.5b00189

Gunduz I, Kondylis A, Jaccard G, Renaud JM, Hofer R, Ruffieux L et al (2016) Tobacco-specific N-nitrosamines NNN and NNK levels in cigarette brands between 2000 and 2014. RTP 76:113-120. https:// doi.org/10.1016/j.yrtph.2016.01.012

Hajek P, Phillips-Waller A, Przulj D, Pesola F, Myers Smith K, Bisal N et al (2019) E-cigarettes compared with nicotine replacement therapy within the UK stop smoking services: the TEC RCT. Health Technol Assess. https://doi.org/10.3310/hta23430

Hang B, Wang Y, Huang Y, Wang P, Langley SA, Bi L et al (2018) Short-term early exposure to thirdhand cigarette smoke increases lung cancer incidence in mice. Clin Sci 132(4):475-488. https:// doi.org/10.1042/CS20171521

Hatoun J, Davis-Plourde K, Penti B, Cabral H, Kazis L (2018) Tobacco control laws and pediatric asthma. Pediatrics 141(Supplement 1): 130-136. https://doi.org/10.1542/peds.2017-1026P

Hecht SS (2012) Lung carcinogenesis by tobacco smoke. Int J Cancer 131:2724-2732. https://doi.org/10.1002/ijc. 27816

Hilton S, Weishaar H, Sweeting H, Trevisan F, Katikireddi SV (2016) Ecigarettes, a safer alternative for teenagers? A UK focus group study of teenagers' views. BMJ Open 6(11):e013271. https://doi.org/10. 1136/bmjopen-2016-013271

Horinouchi T, Higashi T, Mazaki Y, Miwa S (2016) Carbonyl compounds in the gas phase of cigarette mainstream smoke and their pharmacological properties. Biol Pharm Bull 39:909-914. https:// doi.org/10.1248/bpb.b16-00025

IARC (2013) Air pollution and cancer. In: Straif K, Cohen A, Samet J (eds) IARC Scientific Publication No. 161. IARC, Lyon

IARC (2019) IARC monographs on the identification of carcinogenic hazards to humans List Classif. Agents Classif. IARC Monogr (vol 1). IARC, Lyon

Ivashynka A, D’Alfonso S, Copetti M, Naldi P, Fontana A, Cucovici A, Leone M (2019) Effects of cigarette smoking and smoking cessation on multiple sclerosis severity: a cross-sectional study (P4.6-008). Neurology 92:P4.6-P008. https://doi.org/10.13140/RG.2.2.13408. 84486

Jha P (2020) The hazards of smoking and the benefits of cessation: a critical summation of the epidemiological evidence in high-income countries. Elife 9:e49979. https://doi.org/10.7554/eLife.49979

Ji M, Zhang Y, Li N, Wang C, Xia R, Zhang Z et al (2017) Nicotine component of cigarette smoke extract (CSE) decreases the cytotoxicity of CSE in BEAS-2B cells stably expressing human cytochrome P450 2A13. Int J Environ Res Public Health 14(10):1221. https:// doi.org/10.3390/ijerph14101221

Jiloha RC (2014) Pharmacotherapy of smoking cessation. Indian J Psychiatry 56(1):87-95. https://doi.org/10.4103/0019-5545.124726

Khan Z, Suliankatchi RA, Heise TL, Dreger S (2019) Naswar (smokeless tobacco) use and the risk of oral cancer in Pakistan: a systematic review with meta-analysis. NTR 21(1):32-40. https://doi.org/10. 1093/ntr/ntx281

Kindvall M, Jonsson L, Schyberg M (2019) Freeze dried oral smokeless tobacco snuff or non-tobacco snuff product and method of manufacturing thereof. Retrieved from https://patents.google.com/ patent/US10278416B2/en

Konstantinou E, Fotopoulou F, Drosos A, Dimakopoulou N, Zagoriti Z, Niarchos A et al (2018) Tobacco-specific nitrosamines: a literature review. Food Chem Toxicol 118:198-203. https://doi.org/10.1016/ j.fct.2018.05.008

Kristjansson AL, Thomas S, Lilly CL, Thorisdottir IE, Allegrante JP, Sigfusdottir ID (2018) Maternal smoking during pregnancy and academic achievement of offspring over time: a registry data-based cohort study. Prev Med 113:74-79. https://doi.org/10.1016/j. ypmed.2018.05.017

Kumar A, Bhartiya D, Kaur J, Kumari S, Singh H, Saraf D et al (2018) Regulation of toxic contents of smokeless tobacco products. Indian J Med Res 148(1):14. https://doi.org/10.4103/ijmr.IJMR_2025_17

Kurgat C, Kibet J, Cheplogoi P (2016) Molecular modeling of major tobacco alkaloids in mainstream cigarette smoke. Chem Cent J 10: 43. https://doi.org/10.1186/s13065-016-0189-5

Lachenmeier DW, Anderson P, Rehm J (2018) Heat-not-burn tobacco products: the devil in disguise or a considerable risk reduction? Int $\mathrm{J}$ Alcohol Drug Res 7(2):8-11. https://doi.org/10.7895/ijadr.250

Langley TE (2019) Tobacco harm reduction: making sure no one gets left behind. Nicotine Tob Res 21(1):1-2. https://doi.org/10.1093/ntr/ nty 186

Law AD, Fisher C, Jack A, Moe LA (2016) Tobacco, microbes, and carcinogens: correlation between tobacco cure conditions, tobaccospecific nitrosamine content, and cured leaf microbial community. Microb Ecol 72(1):120-129. https://doi.org/10.1007/s00248-0160754-4

Lazard AJ, Kowitt SD, Huang L-L, Noar SM, Jarman KL, Goldstein AO (2018) Believability of cigarette warnings about addiction: national experiments of adolescents and adults. NTR 20(7):867-875. https:// doi.org/10.1093/ntr/ntx185

Lee DC, Crosier BS, Borodovsky JT, Sargent JD, Budney AJ (2016) Online survey characterizing vaporizer use among cannabis users. Drug Alcohol Depend 159:227-233. https://doi.org/10.1016/j. drugalcdep.2015.12.020

Leung JM, Yang CX, Tam A, Shaipanich T, Hackett TL, Singhera GK et al (2020) ACE-2 expression in the small airway epithelia of smokers and COPD patients: implications for COVID-19. Eur Respir J. https://doi.org/10.1183/13993003.00688-2020

Li MD (2018) Involvement of variants in gene clusters CHRNA5/A3/B4 on chromosome 15 to smoking behaviors and lung cancer. In: Tobacco smoking addiction: epidemiology, genetics, mechanisms, and treatment. Springer, Singapore, pp 47-69. https://doi.org/10. 1007/978-981-10-7530-8 5

Li MD, Burmeister M (2009) New insights into the genetics of addiction. Nat Rev Genet 10(4):225-231. https://doi.org/10.1038/nrg2536

Li Q, Hempfling WP, Krauss MR (2008) Spray and/or soil treatment of tobacco to reduce TSNAs. United States Patent Appl. Publ. within the TVPP US20080035228. http://europepmc.org/patents/PAT/ US2008202538. Accessed 24 May 2020

Li SH, Sun XD, Wang Y-z, Shi CL, W-b G, Wang W-m et al (2018) Novel mesoporous composite with zeolite-like selectivity to capture tobacco specific nitrosamine NNK. Chem Eng 332:331-339. https://doi.org/10.1016/j.cej.2017.09.090

Liao YT, Tseng HD, Chang PMH, Chu PY, Kuo YJ, Liu CY (2018) Second primary spindle cell carcinoma of oral cavity and oropharynx: a case report and literature review. Reports-Medical Cases, Images and Videos 1(2):16. https://doi.org/10.3390/reports1020016

Lindson-Hawley N, Hartmann-Boyce J, Fanshawe TR, Begh R, Farley $A$, Lancaster $T$ (2016) Interventions to reduce harm from continued tobacco use. Cochrane Database Systemat Rev. https://doi.org/10. 1002/14651858.CD005231

Lippi G, Henry BM (2020) Active smoking is not associated with severity of coronavirus disease 2019 (COVID-19). Eur J Intern Med 75: 107-108. https://doi.org/10.1016/j.ejim.2020.03.014 
Loomis D, Guyton KZ, Grosse Y, El Ghissassi F, Bouvard V, Benbrahim-Tallaa L et al (2017) Carcinogenicity of benzene. Lancet Oncol 18(12):1574-1575. https://doi.org/10.1016/S14702045(17)30832-X

MacNee W, Rabinovich RA, Choudhury G (2014) Ageing and the border between health and disease. Eur Respir J 44(5):1332-1352. https:// doi.org/10.1183/09031936.00134014

Mallock N, Böss L, Burk R, Danziger M, Welsch T, Hahn H et al (2018) Levels of selected analytes in the emissions of "heat not burn" tobacco products that are relevant to assess human health risks. Arch Toxicol 92(6):2145-2149. https://doi.org/10.1007/s00204-0182215-y

McAdam KG, Faizi A, Kimpton H, Porter A, Rodu B (2013) Polycyclic aromatic hydrocarbons in US and Swedish smokeless tobacco products. Chem Cent J 7(1):151. https://doi.org/10.1186/1752-153X-7151

McAdam K, Eldridge A, Fearon IM, Liu C, Manson A, Murphy J et al (2016) Influence of cigarette circumference on smoke chemistry, biological activity, and smoking behaviour. Regul Toxicol Pharmacol 82:111-126. https://doi.org/10.1016/j.yrtph.2016.09. 010

McAdam K, Murphy J, Eldridge A, Meredith C, Proctor C (2018) Integrating chemical, toxicological and clinical research to assess the potential of reducing health risks associated with cigarette smoking through reducing toxicant emissions. Regul Toxicol Pharmacol 95:102-114. https://doi.org/10.1016/j.yrtph.2018.03. 005

McKinney DL, Vansickel AR (2016) Nicotine chemistry, pharmacology, and pharmacokinetics. In: Neuropathology of drug addictions and substance misuse. RD\&E, Altria Client Services, Richmond, pp 93103. https://doi.org/10.1016/B978-0-12-800213-1.00009-2

Miligi L, Buzzoni C, Piro S (2020) Epidemiology of sinonasal cancer. In: Franchi A (ed) Pathology of sinonasal tumors and tumor-like lesions. Springer, Cham, pp 3-17. https://doi.org/10.1007/978-3030-29848-7_ 1

Mishra S, Joseph RA, Gupta PC, Pezzack B, Ram F, Sinha DN et al (2016) Trends in bidi and cigarette smoking in India from 1998 to 2015, by age, gender and education. BMJ Glob Health 1(1): e000005. https://doi.org/10.1136/bmjgh-2015-000005

Mohapatra T (2019) Gutkha and causative factors of gutkha addiction: a sociological study in "twin city" of Odisha. Int J Soc Sci Econ Res 9(3):476-513. https://doi.org/10.5958/2249-6270.2019.00056.4

Moodie C, MacKintosh AM, Gallopel-Morvan K, Hastings G, Ford A (2017) Adolescents' perceptions of an on-cigarette health warning. Nicotine Tob Res 19(10):1232-1237. https://doi.org/10.1093/ntr/ ntw165

Morean ME, Kong G, Cavallo DA, Camenga DR, Krishnan-Sarin S (2016) Nicotine concentration of e-cigarettes used by adolescents. Drug Alcohol Depend 1(167):224-227. https://doi.org/10.1016/j. drugalcdep.2016.06.031

Morgan JC, Byron MJ, Baig SA, Stepanov I, Brewer NT (2017) How people think about the chemicals in cigarette smoke: a systematic review. J Behav Med 40(4):553-564. https://doi.org/10.1007/ s10865-017-9823-5

$\mathrm{Ng}$ QX (2017) A systematic review of the use of bupropion for attentiondeficit/hyperactivity disorder in children and adolescents. J Child Adolesc Psychopharmacol 27(2):112-116. https://doi.org/10.1089/ cap. 2016.0124

NIDA (2020) Trends \& statistics. Retrieved from https://www. drugabuse.gov/related-topics/trends-statistics

Nlemedim ON (2017) Organic chemical compounds in different Brands of Cigarette Smoke. Dissertation, Texas Southern University
O'Brien JL, Langlois PH, Lawson CC, Scheuerle A, Rocheleau CM, Waters MA et al (2016) Maternal occupational exposure to polycyclic aromatic hydrocarbons and craniosynostosis among offspring in the national birth defects prevention study. Birth Defects Res Part A Clin Mol Teratol 106(1):55-60. https://doi.org/10.1002/bdra.23389

O'Connor R, Watson CH, Swan GE, Nettles DS, Geisler RC, Hendershot TP (2020) PhenX: agent measures for tobacco regulatory research. BMJ 29(1):20-26. https://doi.org/10.1136/tobaccocontrol-2019054976

Omari M, Kibet J, Cherutoi J, Bosire J, Rono N (2015) Heavy metal content in mainstream cigarette smoke of common cigarettes sold in Kenya, and their toxicological consequences. Int Res J Environ Sci 4(6):75-79

Osman OF, Elbashir RMI, Abbass IE, Kendrick C, Goyal M, Yap MH (2017). Automated assessment of facial wrinkling: a case study on the effect of smoking. In: 2017 IEEE international conference on systems, man, and cybernetics (SMC). https://doi.org/10.1109/ SMC.2017.8122755

Palmatier RW, Houston MB, Hulland J (2018) Review articles: purpose, process, and structure. J Acad Mark Sci 46:1-5. https://doi.org/10. 1007/s11747-017-0563-4

Panth N, Paudel KR, Parajuli K (2016) Reactive oxygen species: a key hallmark of cardiovascular disease. Adv Med Sci 2016:9152732. https://doi.org/10.1155/2016/9152732

Peeters S, Gilmore AB (2015) Understanding the emergence of the tobacco industry's use of the term tobacco harm reduction in order to inform public health policy. Tob Control 24:182. https://doi.org/10. 1136/tobaccocontrol-2013-051502

Petrick JL, Campbell PT, Koshiol J, Thistle JE, Andreotti G, BeaneFreeman LE et al (2018) Tobacco, alcohol use and risk of hepatocellular carcinoma and intrahepatic cholangiocarcinoma: the liver cancer pooling project. BJC 118(7):1005-1012. https://doi.org/10. 1038/s41416-018-0007-z

Phaniendra A, Jestadi DB, Periyasamy L (2015) Free radicals: properties, sources, targets, and their implication in various diseases. Ind J Clin Biochem 30(1):11-26. https://doi.org/10.1007/s12291-014-0446-0

Pillitteri JL, Shiffman S, Sembower MA, Polster MR, Curtin GM (2020) Assessing comprehension and perceptions of modified-risk information for snus among adult current cigarette smokers, former tobacco users, and never tobacco users. Addict Behav Rep 11:100254. https://doi.org/10.1016/j.abrep.2020.100254

Pineles BL, Park E, Samet JM (2014) Systematic review and metaanalysis of miscarriage and maternal exposure to tobacco smoke during pregnancy. Am J Epidemiol 179:807-823. https://doi.org/ 10.1093/aje/kwt334

Pokhrel P, Herzog TA, Muranaka N, Fagan P (2015) Young adult ecigarette users' reasons for liking and not liking e-cigarettes: a qualitative study. Psychol Health 30(12):1450-1469. https://doi.org/10. 1080/08870446.2015.1061129

Popova L, Lempert LK, Glantz SA (2018) Light and mild redux: heated tobacco products' reduced exposure claims are likely to be misunderstood as reduced risk claims. Tob Control 27:s87. https://doi.org/ 10.1136/tobaccocontrol-2018-054324

Prochaska JJ, Benowitz NL (2019) Current advances in research in treatment and recovery: nicotine addiction. Sci Adv 5(10):9763. https:// doi.org/10.1126/sciadv.aay9763

Reddy K, Kher S, Kathuria H (2020) Prescription medications to help you stop smoking. Am J Respir Crit Care 201(6):11-12

Rehman H, Ullah I, David M, Ullah A, Jahan S (2019) Neonatal exposure to furan alters the development of reproductive systems in adult male Sprague Dawley rats. Food Chem Toxicol 130:231-241. https://doi.org/10.1016/j.fct.2019.05.020 
Riddick M, Marshall J, Parker R (2017) Systems and apparatus for reducing tobacco-specific nitrosamines in dark-fire cured tobacco through electronic control of curing conditions. US Patent US20170055565A1. Retrieved from https://patents.google.com/ patent/US20170055565A1/en

Roemer E, Meisgen T, Diekmann J, Conroy L, Stabbert R (2016) Heterocyclic aromatic amines and their contribution to the bacterial mutagenicity of the particulate phase of cigarette smoke. J Toxlet 243:40-47. https://doi.org/10.1016/j.toxlet.2015.12.008

Santonicola S, Albrizio S, Murru N, Ferrante MC, Mercogliano R (2017) Study on the occurrence of polycyclic aromatic hydrocarbons in milk and meat/fish based baby food available in Italy. Chemosphere 184:467-472. https://doi.org/10.1016/j. chemosphere.2017.06.017

Sapkota M, Wyatt TA (2015) Alcohol, aldehydes, adducts and airways. Biomolecules 5(4):2987-3008. https://doi.org/10.3390/ biom5042987

Schier JG, Meiman JG, Layden J, Mikosz CA, VanFrank B, King BA et al (2019) Severe pulmonary disease associated with electroniccigarette-product use-interim guidance. MMWR Morb Mortal Wkly Rep 68(36):787-790. https://doi.org/10.15585/mmwr. mm6836e 2

Schmidt HD, Rupprecht LE, Addy NA (2018) Neurobiological and neurophysiological mechanisms underlying nicotine seeking and smoking relapse. Mol Neuropsychiatry 4:169-189. https://doi.org/ $10.1159 / 000494799$

Shafik SS, Shafeq OS, Salman MA (2019) The annual inhalation radiation effective dose estimations for hookah tobacco smoking of Baghdad's publics. J Phys Conf Ser 1279:012044. https://doi.org/ 10.1088/1742-6596/1279/1/012044

Shi X, Yang X (2017) Tobacco flavor extract with reduced tsnas. US Patent US20170231267A1. Retrieved from https://patents.google. com/patent/US20170231267A1/en

Shihadeh A, Schubert J, Klaiany J, El Sabban M, Luch A, Saliba NA (2015) Toxicant content, physical properties and biological activity of waterpipe tobacco smoke and its tobacco-free alternatives. BMJ 24(1):22-30. https://doi.org/10.1136/tobaccocontrol-2014-051907

Singh S, Windle SB, Filion KB, Thombs BD, O'Loughlin JL, Grad R, Eisenberg MJ (2020) E-cigarettes and youth: patterns of use, potential harms, and recommendations. Prev Med 133:106009. https:// doi.org/10.1016/j.ypmed.2020.106009

Singhavi H, Ahluwalia JS, Stepanov I, Gupta PC, Gota V, Chaturvedi P et al (2018) Tobacco carcinogen research to aid understanding of cancer risk and influence policy. Laryngoscope Investig Otolaryngol 3(5):372-376. https://doi.org/10.1002/lio2.204

Skjodt N, Mamoshina P, Kochetov K, Cortese F, Kovalchuk A, Aliper A et al (2018) Smoking causes early biological aging: a deep neural network analysis of common blood test results. Eur Respiratory Soc 52:OA3809. https://doi.org/10.1183/13993003.congress-2018. OA3809

Sleiman M, Logue JM, Luo W, Pankow JF, Gundel LA, Destaillats H (2014) Inhalable constituents of thirdhand tobacco smoke: chemical characterization and health impact considerations. Environ Sci Technol 48(22):13093-13101. https://doi.org/10.1021/es5036333

Smith P (2019) E-cigarettes-Tobacco Prevention and Control-Minnesota Department of Health. Retrieved from https://www.health.state.mn. us/ecigarettes

Smith MR, Clark B, Lüdicke F, Schaller J-P, Vanscheeuwijck P, Hoeng J et al (2016) Evaluation of the tobacco heating system 2.2. Part 1: description of the system and the scientific assessment program. Regul Toxicol Pharmacol 81:17-26. https://doi.org/10.1016/j. yrtph.2016.07.006
Soliman M (2018) Cancer causing chemicals, cancer causing substances. IntechOpen, pp 48-56. https://doi.org/10.5772/intechopen.71560

Spahr S, Cirpka OA, Von Gunten U, Hofstetter TB (2017) Formation of $\mathrm{N}$-nitrosodimethylamine during chloramination of secondary and tertiary amines: role of molecular oxygen and radical intermediates. Environ Sci Technol 51(1):280-290. https://doi.org/10.1021/acs. est.6b04780

Stanfill SB (2020) Chapter eight - reducing carcinogen levels in smokeless tobacco products. In: Pickworth WB (ed) Smokeless tobacco products. Elsevier, pp 167-187. https://doi.org/10.1016/B978-0-12818158-4.00008-X

Stepanov I, Biener L, Yershova K, Nyman AL, Bliss R, Parascandola M et al (2014) Monitoring tobacco-specific N-nitrosamines and nicotine in novel smokeless tobacco products: findings from round II of the new product watch. NTR 16(8):1070-1078. https://doi.org/10. 1093/ntr/ntu026

Tsai J, Homa DM, Gentzke AS, Mahoney M, Sharapova SR, Sosnoff CS et al (2018) Exposure to secondhand smoke among nonsmokersUnited States, 1988-2014. Morb mortal Wkly Rep 67(48):1342. https://doi.org/10.15585/mmwr.mm6748a3

Tynan MA, Holmes CB, Promoff G, Hallett C, Hopkins M, Frick B (2016) State and local comprehensive smoke-free laws for worksites, restaurants, and bars-United States, 2015. Morb Mortal Wkly Rep 65(24):623-626

UFDA (2018) Statement from FDA Commissioner Scott Gottlieb, M.D., on new steps to address epidemic of youth e-cigarette use [Press release]. Retrieved from https://www.fda.gov/news-events/pressannouncements/statement-fda-commissioner-scott-gottlieb-mdnew-steps-address-epidemic-youth-e-cigarette-use

Vardavas CI, Nikitara K (2020) COVID-19 and smoking: a systematic review of the evidence. Tob Induc Dis 18:20. https://doi.org/10. $18332 / \mathrm{tid} / 119324$

Vellios N, Ross H, Perucic A-M (2018) Trends in cigarette demand and supply in Africa. PLoS One 13(8):e0202467-e0202467. https://doi. org/10.1371/journal.pone.0202467

Vu AT, Taylor KM, Holman MR, Ding YS, Hearn B, Watson CH (2015) Polycyclic aromatic hydrocarbons in the mainstream smoke of popular US cigarettes. Chem Res Toxicol 28(8):1616-1626. https://doi. org/10.1021/acs.chemrestox.5b00190

Wang J, Yang H, Shi H, Zhou J, Bai R, Zhang M et al (2017) Nitrate and nitrite promote formation of tobacco-specific nitrosamines via nitrogen oxides intermediates during postcured storage under warm temperature. J Chem. https://doi.org/10.1155/2017/6135215

Wang J, Luo Q, Chen R, Chen T, Li J (2020) Susceptibility analysis of COVID-19 in smokers based on ACE2. Preprints. 10.20944/ preprints202003.0078.v1

Warden H, Richardson H, Richardson L, Siemiatycki J, Ho V (2018) Associations between occupational exposure to benzene, toluene and xylene and risk of lung cancer in Montréal. Occup Environ Med 75(10):696-702. https://doi.org/10.1136/oemed-2017-104987

Warek U, Nielsen MT, Xu D, Cui M, Luo X, Jin X et al. (2019) Nitritedegrading and TSNA-degrading bacteria and methods of making and using. US Patent US10226064B2. Retrieved from https:// patents.google.com/patent/US10226064B2/en

Warnakulasuriya S, Straif K (2018) Carcinogenicity of smokeless tobacco: evidence from studies in humans \& experimental animals. IJMR 148(6):681. https://doi.org/10.4103/ijmr.IJMR_149_18

Weng MW, Lee HW, Park SH, Hu Y, Wang HT, Chen LC, Rom WN, Huang WC, Lepor H, Wu XR, Yang CS, Tang MS (2018) Aldehydes are the predominant forces inducing DNA damage and inhibiting DNA repair in tobacco smoke carcinogenesis. Proc Natl Acad Sci 115:E6152. https://doi.org/10.1073/pnas.1804869115 
WHO (2019) WHO report on the global tobacco epidemic 2019: offer help to quit tobacco use. Retrieved from https://escholarship.org/ content/qt1g16k8b9/qt1g16k8b9.pdf

Wojtczyk-Miaskowska A, Schlichtholz B (2019) Tobacco carcinogens and the methionine metabolism in human bladder cancer. Mutat Res 782:108281. https://doi.org/10.1016/j.mrrev.2019.06.001

Wright C (2015) Standardized methods for the regulation of cigarettesmoke constituents. Tob Regul Sci 66:118-127. https://doi.org/10. 1016/j.trac.2014.11.011
Xue J, Yang S, Seng S (2014) Mechanisms of cancer induction by tobacco-specific NNK and NNN. Cancers 6(2):1138-1156. https:// doi.org/10.3390/cancers6021138

Zamora R, Hidalgo FJ (2020) Formation of heterocyclic aromatic amines with the structure of aminoimidazoazarenes in food products. Food Chem 313:126-128. https://doi.org/10.1016/j.foodchem.2019. 126128

Publisher's note Springer Nature remains neutral with regard to jurisdictional claims in published maps and institutional affiliations. 